\title{
Nutritional Composition of Functional Extrudates Developed from Wheat and Black Gram
}

\author{
Anjali and Varsha Rani* \\ Department of Foods and Nutrition, COHS, CCS Haryana Agricultural University, Hisar, \\ Haryana, India \\ *Corresponding author
}

\begin{tabular}{|l|}
\hline Ke y w o r d s \\
Macaroni, Noodles, \\
$\begin{array}{l}\text { Protein, Minerals, } \\
\text { Sugars, Fiber, } \\
\text { Digestibility }\end{array}$ \\
\hline Article Info \\
\hline $\begin{array}{l}\text { Accepted: } \\
\text { 04 July 2018 } \\
\text { Available Online: } \\
\text { 10 August } 2018\end{array}$ \\
\hline
\end{tabular}

\section{A B S T R A C T}

In current scenario where the burden of nutritional deficiencies, allergic conditions, and progression of degenerative diseases is so increasing due to highly polluted food ingredients, the consumers have become more conscious about healthy eating based on the consumption of functional foods. Black gram is perfect combination of all nutrients, which includes proteins, carbohydrates, fat, ash, zinc, iron and calcium. It stands next to soybean in its dietary protein content. This study was conducted to develop the macaroni and noodles using composite flour of wheat and black gram (85:15). The proximate, sugars, anti-nutrients, total and available minerals and in vitro digestibility of starch and protein of macaroni and noodles were analyzed using standard methods. To compare the means and standard deviations of various parameters between control and supplemented macaroni independent t-test was applied on data. The crude protein, fat, ash and crude fiber contents in macaroni and noodles supplemented with 15 per cent black gram flour ranged from 11.21 to $11.63,13.37$ to $13.83,3.52$ to 3.86 and 2.98 to 3.10 per cent, respectively. Results showed that black gram supplemented noodles and macaroni had significantly $(P \leq 0.05)$ higher contents of crude protein, crude fat, crude fiber, ash, calcium, iron, zinc, available calcium and available iron than that of control products using whole wheat flour. Black gram up to 15 per can be successfully incorporated cent in the development of macaroni and noodles to enhance the nutritive value without affecting their sensory attributes.

\section{Introduction}

Noodles and macaroni are very popular pasta products in India and the most preferred food among children and adolescents (Sanghvi, 2008). The increasing production and popularity of pasta products in India could be attributed to its, low cost, ease of preparation, sensory quality and good storage stability (Sowbhagya and Ali, 2001). A variety of snack foods and breakfast cereals can be produced using extrusion. Extrusion could be used to produce innovative products such as cereal-based snacks, precooked breakfast cereals, etc. Extrusion technique is one of the most common and popular processing techniques among the manufacturers due to its convenience and affordability. Extrusion cooking has been investigated as a means of producing snacks that can be tailored to meet the dietary requirements of particular groups of the population. The development of 
composite extrudates with the mixture of starchy raw materials with other high quality raw material has been an alternative for obtaining extruded snacks with better sensory, physic-chemical and nutritional characteristics (Guy, 2001). The use of high quality protein yielded from inexpensive resources like cereal-pulse based composite flour might be the judicious solution in eradicating protein energy malnutrition which is highly prevalent among children.

Development of baked and extruded products prepared with cereal-pulse composite flour can dramatically improve the protein quality of final product as the composition of amino acids in their proteins is complement to each other. The cereals have been found to be deficient in one or more essential amino acids like lysine and threonine another side there is a lack of methionine in pulse protein. There are enough scientific evidences which confirm the product quality enhancement (Zhao et al., 2005; Herken et al., 2006; Shogren et al., 2006; Wood, 2009) both in terms of sensory and nutritionally. As the cereals are starchy staple and contain optimum amount of protein which is again incomplete in terms of essential amino acids, the pulses- cereals based composite flour become the judicious alternate.

Black gram is perfect combination of all nutrients, which includes proteins (23\%), carbohydrates $(51 \%)$, fat $(1.7 \%)$, ash $(3.17 \%)$, zinc $(3.00 \mathrm{mg})$, iron $(5.97 \mathrm{mg})$ and calcium $(55.64 \mathrm{mg})$. It stands next to soybean in its dietary protein content. Keeping in view the consumer demand of value added extruded products from whole wheat grain flour supplemented with pulses flour and unavailability of these products in current market, the present study was designed to develop black gram supplemented macaroni and noodles and to analyze nutritional composition of the same.

\section{Materials and Methods}

The bulk samples of black gram variety (UH01) and wheat variety (WH-711) were procured from the Pulses section and Wheat and Barley section of Department of Genetics and Plant Breeding, CCSHAU, Hisar, respectively. Other ingredients used in the preparation of different baked and extruded products were procured from the local market in a single lot. The wheat and black gram grains were cleaned of dust and other foreign material. Macaroni and noodles were prepared by incorporating 15 per cent black gram flour along with wheat flour in extrusion machine.

Protein, fat, crude fibre, ash were determined by the standard method of AOAC (2010). A factor of 6.25was applied to convert the amount of nitrogen to crude protein. Total soluble sugars were extracted by refluxing in 80 per cent ethanol by the method of Cerning and Guilhot (1973). Starch from sugar free pellet was extracted in 52 per cent perchloric acid at room temperature by employing the method of Clegg (1956). Quantitative determination of total soluble sugars and starch was carried out by Colorimetric method. Reducing sugars were estimated by Somogy's modified method (1945). Non reducing sugars were determined by calculating the difference between total soluble sugars and reducing sugars. Phytic acid was determined colorimetrically using a spectrophotometer at $465 \mathrm{~nm}$ (Davies and Reid, 1979). The amount of phenolic compounds was estimated as tannic acid equivalent according to Folin-denis reagent (Swain and Hills, 1956).

Starch digestibility (in vitro) was assessed by employing pancreatic amylase and incubating at $37^{\circ} \mathrm{C}$ for two hours. Liberated maltose was measured colorimetrically by using dinitrosalicylic acid reagent at $550 \mathrm{~nm}$ (Singh et al., 1982). Protein digestibility (in vitro) 
was carried out by the modified method of Mertz et al., (1983). The nitrogen contents of the sample and the undigested residue were determined by the micro-kjeldhal method of AOAC (2010). The digested protein of the sample was calculated by subtracting residual protein from total protein of the sample and per cent protein digested was calculated. For the determination of minerals, samples were digested in di-acid mixture. Calcium, iron and zinc were determined by atomic absorption spectrophotometer according to the method of Lindsey and Norwell (1969), whereas phosphorus was determined colorimetrically by the method of Chen et al., 1956. Available calcium in the samples of black gram and wheat were extracted by method of Kim and Zemel (1986). Ionizable iron in the samples was extracted according to the procedure of Rao and Prabhavati (1978).

\section{Statistical analysis}

Statistically data were analyzed using SPSS statistical package (version 11.0) for windows (SPSS Inc., Chicago IL, USA). To compare the means and standard deviations of various parameters between control and supplemented macaroni independent t-test was applied on data.

\section{Results and Discussion}

The moisture content of developed macaroni ranged between 61.46 to 63.60 per cent. However, it did not differ significantly between the macaroni developed using 15 per cent level of black gram flour and control (wheat flour). The contents of crude protein, fat, ash and crude fiber of 15 per cent black gram supplemented macaroni were significantly $(P \leq 0.05)$ higher than that of control macaroni. The moisture content of developed noodles ranged between 58.0260.60 per cent. However, it did not differ significantly between the macaroni developed using 15 per cent level of black gram flour and control. The contents of crude protein, fat, ash and crude fiber of 15 per cent black gram supplemented noodle were also significantly $(P \leq 0.05)$ higher than that of control noodles. The results of present are corroborated with those of Reddy et al., (2014) who explored that the fiber content of the RTE extruded snack developed using corn, black gram and roots and tubers was increased two-fold on addition of roots and tuber flours along with corn and black gram than RTE developed from refined flour. The protein content of the control and the experimental samples were in the range 10.46 to $11.91 \mathrm{~g}$. The highest protein content of $11.91 \pm 0.29 \mathrm{~g}$ was seen in extrudates made from corn, black gram and beetroot flours. In another study an increase in protein and ash contents was observed when the level of black gram semolina increased in blend. The protein content in blended pasta ranged between $14.48-19.85$ per cent with 2575 per cent inclusion of black gram semolina (Rajiv et al., 2015) (Table 1).

Total soluble sugar, non-reducing sugars and starch of control macaroni were significantly $(P \leq 0.05)$ higher than that of macaroni prepared with incorporation of black gram flour (WF: BF (85:15)). There was a nonsignificant decrease in the reducing sugar content of control macaroni and black gram supplemented macaroni (Table 2). The data on carbohydrate composition of noodles showed similar pattern as of macaroni; differences were significant in total soluble sugar, nonreducing sugars and starch of control noodles when compared to composite flour noodles (WF:BF::85:15); but non-significant in the reducing sugar content of two types of noodles. The in vitro protein and starch digestibility of products is highly affected by the presence of anti-nutrients. The in vitro protein and starch digestibility of two types of macaroni ranged between 71.14 to 75.47 and 34.79 to 36.99 per cent respectively. 
Table.1 Proximate composition of macaroni and noodles developed using black gram and wheat composite flour (\%, dry matter basis)

\begin{tabular}{|c|c|c|c|c|c|}
\hline Products & $\begin{array}{l}\text { Moisture } \\
(\mathrm{g} / 100 \mathrm{~g})\end{array}$ & $\begin{array}{l}\text { Crude Protein } \\
\text { (g/100g) }\end{array}$ & $\begin{array}{l}\text { Crude Fat } \\
\text { (g/100g) }\end{array}$ & $\begin{array}{l}\text { Ash } \\
\text { (g/100g) }\end{array}$ & $\begin{array}{l}\text { Crude Fiber } \\
\text { (g/100g) }\end{array}$ \\
\hline \multicolumn{6}{|l|}{ Macaroni } \\
\hline Control (Wheat) & $61.46 \pm 1.28$ & $9.49 \pm 0.44$ & $12.22 \pm 1.92$ & $2.49 \pm 0.20$ & $2.51 \pm 0.10$ \\
\hline WF:BF (85:15) & $63.60 \pm 1.21$ & $11.21 \pm 0.08$ & $13.37 \pm 1.30$ & $3.86 \pm 0.00$ & $3.10 \pm 0.13$ \\
\hline t value $(P \leq 0.05)$ & $0.84^{\mathrm{NS}}$ & $2.80 *$ & $3.60 *$ & $2.86^{*}$ & $2.79 *$ \\
\hline \multicolumn{6}{|l|}{ Noodles } \\
\hline Control (Wheat) & $58.02 \pm 1.22$ & $9.82 \pm 0.58$ & $12.50 \pm 2.18$ & $2.16 \pm 0.06$ & $2.33 \pm 0.12$ \\
\hline WF:BF (85:15) & $60.60 \pm 0.52$ & $11.63 \pm 0.31$ & $13.83 \pm 2.68$ & $3.52 \pm 0.21$ & $2.98 \pm 2.66$ \\
\hline$t$ value $(P \leq 0.05)$ & $0.60^{\mathrm{NS}}$ & $2.89 *$ & $2.79 *$ & $2.90 *$ & $2.82 *$ \\
\hline
\end{tabular}

Values are mean \pm SD of three independent determinations $\mathrm{WF}=$ Wheat flour $\mathrm{BF}=$ Black gram Flour

Table.2 Carbohydrate composition of macaroni and noodles developed using black gram and wheat composite flour $(\mathrm{g} / 100 \mathrm{~g}$, dry matter basis)

\begin{tabular}{|c|c|c|c|c|}
\hline Products & $\begin{array}{l}\text { Total soluble } \\
\text { sugar }\end{array}$ & $\begin{array}{l}\text { Non reducing } \\
\text { sugar }\end{array}$ & $\begin{array}{l}\text { Reducing } \\
\text { sugar }\end{array}$ & Starch \\
\hline \multicolumn{5}{|l|}{ Macaroni } \\
\hline control (Wheat) & $4.91 \pm 0.14$ & $3.45 \pm 0.18$ & $1.46 \pm 0.08$ & $59.47 \pm 0.14$ \\
\hline WF:BF (85:15) & $3.69 \pm 0.16$ & $2.46 \pm 0.17$ & $1.23 \pm 0.07$ & $56.83 \pm 0.16$ \\
\hline$t$ value $(P \leq 0.05)$ & $4.50 *$ & $4.48 *$ & $2.54^{\mathrm{NS}}$ & $4.32 *$ \\
\hline \multicolumn{5}{|l|}{ Noodles } \\
\hline Control (Wheat) & $4.90 \pm 0.14$ & $3.64 \pm 0.17$ & $1.26 \pm 0.09$ & $58.36 \pm 0.19$ \\
\hline WF:BF (85:15) & $3.58 \pm 0.09$ & $2.40 \pm 0.06$ & $1.18 \pm 0.08$ & $54.55 \pm 0.15$ \\
\hline$t$ value $(P \leq 0.05)$ & $3.21 *$ & $3.08 *$ & $1.10^{\mathrm{NS}}$ & $3.39 *$ \\
\hline
\end{tabular}

Values are mean \pm SD of three independent determinations

$\mathrm{WF}=$ Wheat flour $\mathrm{BF}=$ Blackgram Flour

Table.3 In vitro protein and starch digestibility and antinutrients of macaroni and noodles developed using black gram and wheat composite flour (\%, dry matter basis)

\begin{tabular}{|c|c|c|c|c|}
\hline Products & $\begin{array}{l}\text { In vitro protein } \\
\text { digestibility }(\%)\end{array}$ & $\begin{array}{l}\text { In vitro starch } \\
\text { digestibility }(\%)\end{array}$ & $\begin{array}{l}\text { Phytic acid } \\
\text { (mg/100g) }\end{array}$ & $\begin{array}{l}\text { Polyphenol } \\
\text { (mg/100g) }\end{array}$ \\
\hline \multicolumn{5}{|l|}{ Macroni } \\
\hline Control (Wheat) & $75.47 \pm 0.36$ & $36.99 \pm 0.14$ & $420.69 \pm 0.14$ & $284.18 \pm 0.30$ \\
\hline WF:BF (85:15) & $71.14 \pm 0.41$ & $34.79 \pm 0.17$ & $449.36 \pm 0.15$ & $330.75 \pm 0.22$ \\
\hline$t$ value $\leq 0.05$ & $2.93^{*}$ & $2.80^{*}$ & $2.83 *$ & $2.97 *$ \\
\hline \multicolumn{5}{|l|}{ Noodles } \\
\hline Control (Wheat) & $76.21 \pm 0.36$ & $37.82 \pm 0.11$ & $430.21 \pm 0.59$ & $283.91 \pm 0.35$ \\
\hline WF:BF (85:15) & $72.45 \pm 0.39$ & $34.99 \pm 0.12$ & $453.95 \pm 0.24$ & $305.46 \pm 0.45$ \\
\hline$t$ value $(P \leq 0.05)$ & $2.87 *$ & $2.85^{*}$ & $2.90 *$ & $3.17 *$ \\
\hline
\end{tabular}

Values are mean \pm SD of three independent determinations $\mathrm{WF}=$ Wheat flour $\mathrm{BF}=$ Blackgram Flour 
Table.4 Total and available minerals in macaroni and noodles developed using black gram and wheat $(\mathrm{mg} / 100 \mathrm{~g}$, dry matter basis)

\begin{tabular}{|c|c|c|c|c|}
\hline Products & Calcium & Iron & Available calcium & Available iron \\
\hline \multicolumn{5}{|l|}{ Macaroni } \\
\hline Control (Wheat) & $56.66 \pm 0.76$ & $3.30 \pm 0.06$ & $38.13 \pm 0.07(67.29)$ & $2.13 \pm 0.01(64.70)$ \\
\hline WF:BF(85:15) & $62.33 \pm 1.25$ & $4.50 \pm 0.025$ & $37.27 \pm 0.06(59.80)$ & $2.58 \pm 0.05(57.43)$ \\
\hline$t$ value $(P \leq 0.05)$ & $3.75^{*}$ & $3.80 *$ & $3.46^{*}$ & $3.60 *$ \\
\hline \multicolumn{5}{|l|}{ Noodles } \\
\hline Control (Wheat) & $58.50 \pm 1.00$ & $3.64 \pm 0.30$ & $39.69 \pm 0.14(67.84)$ & $2.26 \pm 0.06(62.18)$ \\
\hline WF:BF (85:15) & $65.66 \pm 1.25$ & $4.28 \pm 0.00$ & $44.54 \pm 0.07(58.76)$ & $2.34 \pm 0.06(54.90)$ \\
\hline$t$ value $(P \leq 0.05)$ & $3.81 *$ & $2.86^{*}$ & $3.82 *$ & $3.28 *$ \\
\hline
\end{tabular}

Values are mean \pm SD of three independent determinations $\mathrm{WF}=$ Wheat flour $\mathrm{BF}=$ Blackgram Flour

The in vitro protein and starch digestibility of control macaroni prepared with whole wheat flour was significantly higher $(P \leq 0.05)$ than the macaroni prepared using 15 per cent supplementation of black gram flour (Table $3)$. The similar trends for in vitro protein and starch digestibility were observed for noodles. The in vitro protein and starch digestibility of two types of noodles ranged between 72.45 to 76.21 and 34.99 to 37.82 per cent respectively. Patil et al., (2016) prepared wheat-based extrudates using four different legume flours i.e. lentil, chickpea, green pea, and yellow pea flour. The effects of adding legumes to wheat-based snacks at different levels $(0,5,10$ and 15\%) during extrusion were investigated in terms of increase in protein and protein digestibility. It was observed that fortification of snacks with legumes caused an increase by 10-15 per cent in the protein content and an increase by 37 62 per cent in protein digestibility. The product developed by extrusion was found to be low in fat and moisture content. In their study they also confirmed that extrusion process increases the protein digestibility.

Significant $(P<0.05)$ differences were existed in the phytic acid contents of control macaroni and noodles when these were compared to the macaroni and noodles supplemented with 15 per cent of black gram flour; it was higher in supplemented products. Similar trend was observed for polyphenols contents that it was also found significantly $(P<0.05)$ higher in the supplemented products. The phytic acid contents of two types of macaroni and noodles ranged between 420.69 to 449.36 and 430.21 to $453.95 \mathrm{mg}$ per $100 \mathrm{~g}$, respectively. Whereas, the polyphenols contents of two types of macaroni and noodles ranged between 284.18 to 330.75 and 283.91 to $305.46 \mathrm{mg}$ per $100 \mathrm{~g}$, respectively.

Black gram supplemented macaroni and noodles had significantly $(P<0.05)$ higher amount of calcium, iron and zinc when compared to that of control macaroni and noodles. The calcium, zinc and iron in two types of macaroni ranged between 56.66 to $62.33,2.93$ to 3.50 and $3.30-4.50 \mathrm{mg}$ per 100 gram, respectively. Though the contents of same parameters were slightly higher in the two types of noodles and ranged between 58.50 to $65.66,2.87$ to 3.42 and 3.64 to 4.28 $\mathrm{mg}$ per 100 gram, respectively. Both the contents as well as per cent availability of calcium and iron in control macaroni was significantly higher $(P \leq 0.05)$ as compared with the black gram supplemented macaroni. The similar trends were observed for the 
contents and per cent availability of calcium and iron in control as well as black gram supplemented noodles. The per cent availability of calcium and iron between two types of macaroni and noodles ranged between 59.80 to 67.29 and 2.13 to 2.58 respectively in macaroni and 39.69 to 44.54 and 2.26 to 2.34 , respectively in noodles (Table 4).

The results of the present study indicated that 15 per cent black gram flour in the development of macaroni and noodles can be successfully incorporated to enhance the nutritive value of these products without affecting their sensory attributes. Moreover, the black gram and wheat composite flour based products possess the best protein quality as the combination provide maximum essential amino acids therefore it could be better solution for combating protein energy malnutrition among growing children.

\section{References}

AOAC 2010. Official methods of analysis of the AOAC international. Association of Official Analytical Chemists, Washington DC.

Cerning, J. and Guilhot, J. 1973. Changes in carbohydrate composition during maturation of wheat and barley kernel. Cereal Chem. 50: 220-222.

Clegg, K.M. 1956. The application of anthrone reagent to the estimation of starch cereals. J. Sci. Fd. Chem. Agric. 7: 40-44.

Davies, N.T. and Reid, H. 1979. An evaluation of phytate, zinc, copper, iron and magnesium content and availability from soya-based textured vegetables. Brit. J. Nutr. 41: 579.

Guy, R. 2001. Extrusion cooking, technologies and application. Florida: Woodhead Publication. 151.
Herken, E.N, Ibanoglu S, Oner MD. and Ibanoglu E. 2006. The in vitro protein digestibility, microbiological quality and gelatinization behavior of macaroni as affected by cowpea flour addition. Fd. Chem. 98: 664-669.

Kim, H. and Zemel, M.R. 1986. In vitro estimation of the potential bioavailability of calcium from sea mustard,milk and spinach under stimulated normal and reduced gastric acid conditions. J. Food. Sci. 51: 957963.

Lindsay, W.L. and Norwell W.A. 1969. A micronutrient soil test for $\mathrm{Zn}, \mathrm{Fe}, \mathrm{Mn}$, and $\mathrm{Cu}$. Agron. Abstr. 84.

Mertz, E.T., Kirileis, A.W. and Aretell, J.D. 1983. In vitro digestibility of protein in major food cereals. Fed. Proc. 42(5): 6026-6028.

Patil, S.S., Brennan, M.A., Mason, S.L., Brennan. and Brennan, C.S. 2016. The Effects of fortification of legumes and extrusion on the protein digestibility of wheat based snack. Foods: 1-8.

Rajiv, J., Milind, Inamdar, A.A., Sakhare, S.G. and Rao, V. 2015. Developed roller milled blackgram (Phaseolus mungo) semolina and its influence on the quality charecteristics of high protein pasta. J. Fd. Sci. Tech. 52(4). 2464-246.

Rao, B.S.N. and Parbhavathi, T. 1978. An in vitro method for predicting the bioavailability of iron from foods. Am. J. of Clin. Nutr. 31: 169-175.

Reddy, M.K., Kuna,A., Devi,L.N., Krishnaiah,N., Kaur,C. and Nagamalleswari,Y. 2014. Development of extruded Ready-To-Eat (RTE) snacks using corn, black gram, roots and tuber flour blends. J. Fd. Sci. Tech. 51(9): 1929-1937.

Sanghvi, R. 2008. Process Technique: Pasta, Loved by young and old alike. Processed Fd. Indu. 3: 32- 41. 
Shogren, R.L, Hareland, G.A. and Wu, Y.V. 2006. Sensory evaluation and composition of spaghetti fortified with soya flour. $J$ Fd. Sci 71: S428-S432.

Singh U, Khedekar MS and Jambunathan R. 1982 Studies on desi and kabuli chickpea cultivars. The level of amylase inhibitors, levels of oligosaccharides and in vitro starch digestibility. Journal of food science 47: 510 .

Singh, U. and Jambunathan, R. 1981. Studies on desi and kabuli chickpea culivars, levels of protease inhibitors, poly phenolic compound and in vitro protein digestibility. J. Fd. Sci. Tech. 43(3): 322-324.

Somogyi, A.K. and Rao, H.P. 1945. Studies on low fat dough biscuits. J. Fd. Sci. Nutr. 65(6): 661-666.
Sowbhagya, C.M., Ali, Z.S. 2001. Vermicelli noodles and their quality assessment. $J$. Fd. Sci. Technol. 38: 423-432.

Swain, J. and Hills, W. E. 1959. The phenolic constituents of Pramus domesiicai. The qualitative analysis of phenolic constituents. J. Sci. and Fd. Agri. 10: 63-68

Wood, J.A. 2009. Texture, processing and organoleptic properties of chickpea fortified spaghetti with insights to underlying mechanisms of traditional durum pasta quality. J. Cereal Sci. 49: 128-133.

Zhao, Y.H., Manthey, F.A., Chang, S.K.C., Hou, H.J., Shaohong, H.Y. 2005. Quality characteristics of spaghetti as affected by green and yellow pea, lentil and chickpea flours. J. Fd. Sci 70: S371-S376.

\section{How to cite this article:}

Anjali and Varsha Rani. 2018. Nutritional Composition of Functional Extrudates Developed from Wheat and Black Gram. Int.J.Curr.Microbiol.App.Sci. 7(08): 375-381. doi: https://doi.org/10.20546/ijcmas.2018.708.042 